\title{
Asidifikasyon İşleminin Laurocerasus officinalis Ekstraktlarının Antioksidan Özellikleri Üzerine Etkisinin İncelenmesi
}

\author{
Feyza DEMİR ${ }^{1}$, Yüksel ALIYAZICIOĞLU ${ }^{1}$, Selim DEMİR ${ }^{2 *}$
}

\author{
${ }^{1}$ Karadeniz Teknik Üniversitesi, Tıp Fakültesi, Tıbbi Biyokimya Anabilim Dalı, 61080, Trabzon, Türkiye \\ ${ }^{2}$ Karadeniz Teknik Üniversitesi, Sağlık Bilimleri Fakültesi, Beslenme ve Diyetetik Bölümü, 61080, Trabzon, \\ Türkiye; e-mail: selim-demir@hotmail.com
}

Received/Geliş: 21.04 .2017

Revised/Düzeltme: 29.05.2017 Accepted/Kabul: 30.05.2017

Özet: Laurocerasus officinalis Roem. Prunus cinsine ve Rosaceae familyasına mensup bir tür olup, Türkiye'de halk arasında "karayemiş" veya "taflan" adı ile bilinmektedir. Diyetsel fenolik bileşikler doğal antioksidan maddeler olup, bitkisel kaynaklarda aglikon halde bulunabildikleri gibi glikozile halde de bulunabilmektedirler. Genel kanı antioksidan aktivitelerinin hidroksil grubu sayısıyla orantılı olarak arttığı ve glikozilasyon derecesi ile orantılı şekilde azaldığı yönündedir. Çeşitli çalışmalarda uygulanan asidifikasyon işleminin doğal ürünlerden elde edilen ekstraktların antioksidan gücünü asidifikasyon uygulanmayan ham ekstraktlara göre arttırdığı gösterilmiştir. Bu çalışmanın amacı farklı çözücülerle hazırlanmış $L$. officinalis ekstraktlarının asidifikasyon işlemi sonucu antioksidan özelliklerindeki değişikliklerin belirlenmesidir. Çalışmada L. officinalis'in etanol, dimetil sülfoksit (DMSO) ve bu çözücülerin $\% 0.5(\mathrm{v} / \mathrm{v})$ oranında hidroklorik asit içeren formları ile dört farklı ekstrakt hazırlandı. Ekstraktların antioksidan özellikleri toplam fenolik madde tayini, toplam flavonoid madde tayini, demir indirgeyici güç tayini ve 2,2-difenil-1-pikrilhidrazil (DPPH) radikal temizleme aktivitesi metotları kullanılarak belirlendi. DMSO ile hazırlanan ekstraktın antioksidan aktivite değerleri etanollü ekstrakta göre istatistiksel olarak anlamlı derecede yüksek bulundu $(\mathrm{p}<0.05)$. Asidifikasyon işleminin her iki çözücüyle de hazırlanan ekstraktların antioksidan özelliklerini istatistiksel olarak anlamlı derecede arttırdığı gözlendi $(\mathrm{p}<0.05)$. Asidifikasyon işlemi sonucu antioksidan aktivite değerlerindeki yükselmenin biyolojik aktivitelere ne oranda yansıdığının gösterilmesi için daha kapsamlı çalışmalar gerekmektedir.

Anahtar kelimeler: Antioksidan aktivite, Fenolik bileşikler, Karayemiş, Laurocerasus officinalis

\section{Investigation of the Effect of Acidification Process on Antioxidant Properties of Laurocerasus officinalis Extracts}

\begin{abstract}
Laurocerasus officinalis Roem. belongs to the genus Prunus and the family Rosaceae and also locally known as "karayemis" or "taflan" in Turkey. Dietary phenolic compounds are natural antioxidants and can be present in vegetable sources as well as in aglycone form or in glycoside form. The general opinion is that their antioxidant activities increases in proportion to the number of hydroxyl groups and decreases in proportion to the degree of glycosylation. It has been shown that in various studies the acidification process applied increases the antioxidant power of the extracts obtained from the natural products compared to the crude extracts which are not acidified. The aim of this study is to determine the changes in the antioxidant properties of acidified $L$. officinalis extracts prepared with different solvents. In the study, four different extracts were prepared from $L$. officinalis using ethanol, dimethyl sulfoxide (DMSO) and $0.5 \%(\mathrm{v} / \mathrm{v})$ hydrochloric acid in the form of these solvents. The antioxidant properties of the extracts were determined using the total phenolic content, total flavonoid content, iron reducing power assay, and 2,2-diphenyl-1-picrylhydrazyl (DPPH) radical scavenging
\end{abstract}


activity. The antioxidant activity values of the DMSO extract were statistically significantly higher than the ethanolic extract $(\mathrm{p}<0.05)$. It was observed that the acidification process statistically significantly increased the antioxidant properties of the extracts prepared with both solvents $(p<0.05)$. More extensive studies are needed to show how the increase in antioxidant activity values after acidification reflects on biological activities.

Keywords: Antioxidant activity; Cherry laurel; Laurocerasus officinalis; Phenolic compounds

\section{Giriş}

Laurocerasus officinalis Roem. (Prunus laurocerasus L.) Prunus cinsi ve Rosaceae familyasına mensup bir tür olup, İngilizce literatürde "cherry laurel" adıyla da bilinmektedir. Türkiye'de halk arasında "karayemiş" veya "taflan" adı ile bilinen bu meyvenin değişik türlerine Batı Avrupa, Balkanlar ve Kafkasya gibi bölgelerde de rastlanılmaktadır. Türkiye'de ise karayemiş yetiştiriciliği için en uygun iklim şartlarına Doğu Karadeniz Bölgesi'nin sahip olduğu bildirilmektedir [1]. $L$. officinalis meyvesi monosakaritler, askorbik asit, diyet lifi, çeşitli mineraller ile klorojenik, benzoik, vanilik ve kafeik asit gibi fenolik bileşiklerce zengin olmasından dolayı iyi bir besin kaynağı olarak kabul edilmektedir [2]. L. officinalis geleneksel tedavide, egzema, boğaz ağrısı, bronşit, astım, öksürük, mide ağrısı, diyabet ve hemoroid gibi birçok rahatsılı̆̆ın tedavisinde kullanılmaktadır $[1,2]$. Son yıllarda yapılan bilimsel çalışmalarda ise L. officinalis'in anti-inflamatuar, antioksidan, antidiyabetik ve kanser hücrelerine karşı sitotoksik etkilerinin olduğu ortaya konulmuştur [1-4].

Reaktif oksijen türleri (ROS) normalde vücut içerisinde sınırlı miktarda üretilen, homeostazın korunması, sinyal iletimi, gen ifadesi ve reseptörlerin aktivasyonu gibi hücresel işlevleri içeren süreçlerin düzenlenmesinde rol oynayan önemli bileşiklerdir. Oksidatif stres, hücrelerdeki artmış ROS üretimi ve/veya onları ortadan kaldırmakla yükümlü antioksidan sistemin yetersizliği sonucu ortaya çıkan durumdur. Oksidan/antioksidan dengenin bozulması sonucu hücrelerde miktarı artan ROS'lar lipidler, proteinler, karbohidratlar ve nükleik asitler gibi biyomoleküllere zarar vermektedirler. Günümüzde biyomoleküllerde ROS kaynaklı meydana gelen zararlı yapısal değişikliklerin diyabet, kanser, kardiyovasküler ve nörodejeneratif hastalıklar gibi pek çok patolojik durumun etyopatogenezinde rol oynayabileceği ileri sürülmektedir [5,6].

Fenolik bileşikler bitkileri ultraviyole 1şınlardan ve patojenlerden korumakla görevli sekonder metabolitler olup meyve, sebze ve tahıllar gibi doğal ürünlerde bol miktarda bulunmaktadırlar. Bugüne kadar 8000'den fazla bitkisel kaynaklı fenolik bileşik tespit edilmiştir [6]. Diyetsel fenoliklerin antioksidan özelliklerinin yanı sıra anti-inflamatuar, yaşlanmayı geciktirici, antiaterosklerotik ve antikanser özellikler gibi biyolojik aktiviteler sergileyebildikleri ortaya konulmuştur [7]. Her sene artan sayıda gerçekleştirilen epidemiyolojik, klinik ve beslenme çalışmaları, diyetsel fenolik bileşiklerin kontrollü ve periyodik tüketiminin kanser, kardiyovasküler ve nörodejeneratif hastalıklar gibi metabolik bozuklukların oluşma riskini azalttığını ortaya koymaktadır. Bitkilerin kimyasal savunmasının da bir parçası olan fenolik bileşikler, bitkilerde serbest fenolik bileşik (aglikonlar) şeklinden daha çok glikozid, açilglikozid veya diğer konjuge formları şeklinde bulunmaktadırlar. Mikrobiyal istila ya da abiyotik stres durumlarında ise bu glikozidik fenolikler hızla daha etkili olan aglikonları şekline dönüştürülmektedirler. Diyetle bitkisel kaynaklardan alınan fenoliklerin büyük bir kısmı glikozidleri şeklinde olup, glikozidlerin bağırsak emilimi aglikonlara göre daha zayıftır. Bu nedenle glikozid türevi fenolik bileşikler ince bağırsak florasında aglikonları şekline dönüştürülmekte, dönüştürülemeyen kısım ise feçesle atılmaktadir [8].

Doğal ürünlerden elde edilen ekstraktların antioksidan özelliklerinin incelendiği çalışmalarda hem glikozile fenolik bileşiklerin vücutta maruz kaldığı deglikozilasyon işlemini in vitro koşullarda da oluşturabilmek, hem de yapılarında bulunan antosiyanin gibi antioksidan bileşiklerin kararlılığını arttırabilmek adına ekstraksiyon aşamasında çözücü içerisine yapıyı bozmayacak 
konsantrasyonlarda asit ilavesi yapılmaktadır [9]. Çeşitli çalışmalarda uygulanan bu asidifikasyon işleminin doğal ürünlerden elde edilen ekstraktların antioksidan gücünü asidifikasyon uygulanmayan ham ekstraktlara göre arttırdığı ortaya konulmuştur. Suganya Devi ve arkadaşları Sorghum bicolor çiçeklerinden hazırladıkları asidifiye metanollü ekstraktların toplam fenolik ve antosiyanin içerik değerlerinin sadece metanol ile hazırlanan ekstraktlara göre daha yüksek seviyede olduğunu gösterirlerken [10], Suresh ve arkadaşları ise Hindistan'dan topladıkları Cassava bitkisinin yapraklarından elde ettikleri asidifiye metanollü ekstraktın toplam fenolik içerik, vitamin C miktar1, 2,2-difenil-1-pikrilhidrazil (DPPH) ve hidroksil radikal temizleme aktiviteleri değerlerinin metanollü ekstrakta göre daha yüksek seviyede olduğunu bildirmişlerdir [11]. $L$. officinalis meyvelerinden elde edilen farklı ekstraktların antioksidan özelliklerinin incelendiği çalışmalar bulunmakla birlikte $[1,2,11,12]$ yapılan literatür taramalarında karayemiş ekstraktlarında asidifikasyon işlemi uygulamasının antioksidan aktiviteyi nasıl etkilediğine dair bir çalışmaya rastlanılmamıştır. Buradan hareketle hazırlanan bu çalışmanın amacı farklı çözücülerle hazırlanmış L. officinalis ekstraktlarının asidifikasyon işlemi sonucu antioksidan özelliklerindeki değişikliklerin belirlenmesidir.

\section{Materyal ve Metot}

\subsection{Materyal}

\subsubsection{Bitkisel Materyal}

Tam olgunlaşmış L. officinalis meyve örnekleri 2013 y1lı Ağustos ayında Trabzon ilinin Ortahisar ilçesinden toplandı. Bitkinin tür teşhisi Gümüşhane Üniversitesi Mühendislik ve Doğa Bilimleri Fakültesi öğretim üyesi Yrd. Doç. Dr. İbrahim Turan tarafindan yapıldı.

\subsubsection{Kullanılan Kimyasal Maddeler}

Antioksidan aktivite analizlerinde kullanılan tüm kimyasallar ve çözücüler analitik ya da HPLC sınıfı saflıkta olup Sigma-Aldrich (St. Louis, ABD) firmasından satın alındı.

\subsubsection{Kullanılan Laboratuvar Cihazları}

$\mathrm{Bu}$ çalışma yapılırken laboratuvar değirmeni (Retsch ZM 200, Haan, Almanya), mikropleyt okuyucu (Molecular Devices Versamax, California, ABD), santrifüj (Eppendorf 5804, Hamburg, Almanya), çalkalayıcılı inkübatör (Shellab, Cornelius, ABD) ve hassas analitik terazi (Mettler Toledo AB204-S, Greifensee, İsviçre) gibi laboratuvar cihazları kullanıldı.

\subsection{Metot}

\subsubsection{Ekstraksiyon}

Toplanan meyveler laboratuvarda oda sicaklığında kurumaya birakıldı. Kuruyan meyve örneklerinin çekirdekleri çıkartıldı. Kalan kurumuş etli kısımları önce blenderde küçültüldü ve sonrasında laboratuvar değirmeninde toz haline getirildi. Toz haline getirilmiş örneklerden hassas terazide 0.5 'er g tartıldı ve dört adet steril falkon tüpüne aktarıldı. Her bir tüpe ayrı ayrı sırasıyla 10 'ar mL etanol ve dimetil sülfoksit (DMSO) ile bu çözücülerin \% $0.5(\mathrm{v} / \mathrm{v})$ hidroklorik asit $(\mathrm{HCl})$ içeren formlarından ilaveler yapıldı. Tüpler vortekslendi ve çalkalayıcılı inkübatörde $45^{\circ} \mathrm{C}$ ' de 150 rpm'de 24 saat süreyle inkübe edildi. İnkübasyon sonrası elde edilen ekstraktlar süzgeç kağıdından süzüldü ve elde edilen süpernatantlar $0.2 \mu \mathrm{m}$ 'lik filtrelerden geçirildi. Böylece 4 farklı çözücü ile 50 'şer $\mathrm{mg} / \mathrm{mL}$ konsantrasyonlarda L. officinalis ekstraktları hazırlandı [2]. Hazırlanan ekstraktlar antioksidan analizlerde kullanılmak üzere $4^{\circ} \mathrm{C}$ 'de saklandı. 


\subsubsection{Ekstraktların Antioksidan Özelliklerinin Belirlenmesi 2.2.2.1. Toplam Fenolik Madde İçeriğinin Belirlenmesi}

Ekstraktların toplam fenolik madde içerikleri, modifiye edilmiş Folin-Ciocalteu metoduna göre spektrofotometrik olarak belirlendi [14]. Yöntem suda veya organik çözücülerde çözünmüş fenolik bileşiklerin Folin reaktifi ile alkali ortamda renkli kompleks oluşturması esasına dayanmaktadır. Oluşan mor-menekşe renkli kompleks $760 \mathrm{~nm}$ 'de maksimum absorbans vermektedir. Tayinlerde standart olarak gallik asit kullanıldı ve fenolik madde miktarı mg gallik aside eşdeğer/g örnek olarak hesaplandi.

\subsubsection{Toplam Flavonoid Madde İçeriğinin Belirlenmesi}

Ekstraktların toplam flavonoid madde içerikleri, alüminyum klorür kolorimetrik metodu ile belirlendi [15]. Yöntem alüminyum klorür'ün flavonlar ve flavonollerin C-4 keto grubu ve C-3 veya C-5 hidroksil grupları ile asidik ortamda kararlı kompleksler oluşturması esasına dayanmaktadır. Oluşan renkli kompleks 415 nm'de maksimum absorbans vermektedir. Tayinlerde standart olarak kuersetin kullanıldı ve flavonoid madde miktarı mg kuersetine eşdeğer/g örnek olarak hesaplandı.

\subsubsection{Demir İndirgeyici Gücün Belirlenmesi}

Demir indirgeyici gücün belirlenmesi için Oyaizu'nun geliştirdiği yöntem kullanıldı [16]. Antioksidanlar gibi indirgen maddelerin varlığ 1 , $\mathrm{Fe}^{3+}$-ferrisiyanür kompleksinin $\mathrm{Fe}^{2+}$ ye indirgenmesine neden olmaktadır $\mathrm{Bu}$ reaksiyon sonucu oluşan yeşil renk $700 \mathrm{~nm}$ 'de maksimum absorbans vermektedir. Tayinlerde standart olarak askorbik asit kullanıldı ve demir indirgeyici güç miktarı mg askorbik aside eşdeğer/g örnek olarak hesaplandı.

\subsubsection{DPPH Radikal Temizleme Aktivitelerinin Belirlenmesi}

Ekstraktların radikal temizleme aktivitelerinin belirlenmesinde Cuendet ve arkadaşlarının geliştirdiği yöntem kullanıldı [17]. DPPH ticari bir radikaldir ve antioksidan karakterde maddelerle muamele edildiğinde karakteristik mor renginin şiddeti azalmaktadır. Absorbanstaki azalma radikal temizleme gücü ile orantılı olup, $517 \mathrm{~nm}$ 'de takip edilmektedir. Tayinlerde standart olarak askorbik asit kullanıldı ve sonuçlar $\mathrm{SC}_{50}$ değerleri cinsinden verildi. Literatürde yayınlar arası bütünlüğün sağlanması için doğal ürün ekstraktı ya da herhangi bir kimyasal maddenin radikal temizleme aktivitesi $\mathrm{SC}_{50}$ değerleri cinsinden ifade edilmektedir. $\mathrm{SC}_{50}$; ortamdaki $\mathrm{DPPH}$ radikalinin verdiği ham absorbans $1 \% 50$ azaltan madde konsantrasyonunu $(\mathrm{mg} / \mathrm{mL})$ tarif etmektedir.

\section{3. İstatistiksel Analiz}

Sonuçlar üç bağımsız deneyin ortalaması ve standart sapma alınarak (aritmetik ortalama \pm standart sapma) hesapland1. Deney sonuçları, SPSS (Statistics Program for Social and Science) 13.0.1 istatistik programına yüklenerek normal dağılıma uygunlukları Kolmogorov-Smirnov testi ile kontrol edildi. Normal dağılıma uygun oldukları görüldükten sonra ANOVA testi, gruplar arasındaki ilişkinin ortaya konabilmesi için ise post-hoc Tukey analizleri kullanıldı. $\mathrm{p}<0.05$ istatistiksel olarak anlamlı kabul edildi.

\section{Bulgular ve Tartışma}

Bitkiler güçlü biyolojik özelliklere sahip biyoaktif bileşiklerin (fenolik bileşikler gibi) önemli bir kaynağını oluştururlar ve dünyadaki çeşitli kültürlerde geleneksel tedavi amacıyla asırlardır kullanılmaktadırlar [18]. L. officinalis Prunus cinsine ve Rosaceae familyasına mensup bir bitki 
olup, Türkiye'de özellikle Doğu Karadeniz Bölgesi'nde yaygın bir şekilde üretilmekte ve tüketilmektedir. Meyvenin geleneksel tedavide siklıkla kullanılmakta olduğu bilinmekte olup, yapılan araştırmalarda meyveden elde edilen ekstraktların antioksidan, antidiyabetik ve antiproliferatif etkilerinin olduğu ortaya konulmuştur [1-4]. Serbest radikal üretimindeki artış ve/veya antioksidan kapasitedeki azalma sonucu ortaya çıkan patolojik durum oksidatif stres olarak isimlendirilmektedir. Artmış ROS'lar proteinlere, lipitlere, nükleik asitlere ve karbohidratlara zarar vererek organizmanın yapısını ve işlevlerini bozabilmektedirler [5]. Bu nedenle antioksidan aktivite, sağlıklı yaşam için vazgeçilmez bir gerekliliktir. Antimutajenik, antikanser, antidiyabetik ve yaşlanmayı geciktirici etki gibi birçok biyolojik fonksiyonun bu temel özellikten kaynaklandığ1 vurgulanmaktadır. Serbest radikallerin hastalıklardaki rolü üzerine bilgiler derinleştikçe, doğal antioksidanlar serbest radikal reaksiyonlarını inhibe edebilmeleri ve canlıları ROS kaynaklı hasarlara karşı koruyabilmeleri kabiliyetleri nedeniyle gün geçtikçe daha popüler hale gelmektedirler. Doğal ürünlerden elde edilen ekstraktlar fenolik bileşikler bakımından zengindir ve lipidlerin oksidatif bozunmasını geciktirdikleri, dolayısıyla yiyeceklerin kalitesini ve besin değerini geliştirdikleri için gıda sanayinde giderek daha fazla ilgi çekmektedirler [18].

Biyoaktif bileşiklerin bitki materyalinden ekstraksiyonu fitokimyasalların, diyet takviyelerinin, gıda katkı maddelerinin, farmasötik ve kozmetik ürünlerinin içeriğinde kullanılabilmesinin ilk adımdır. Ekstraksiyon işleminden önce bitki numuneleri önce kesme, parçalama, öğütme ya da homojenizasyon işlemleri ile kararlı ve küçük fragmentlere ayrılırlar. Daha sonra bu küçük parçalar ekstraksiyon işlemine tabi tutulurlar. Çözücü ekstraksiyonları, kullanım kolaylığı, verimlilik ve geniş uygulanabilirlik nedeniyle bitki materyalinden ekstrakt hazırlamak için en yaygın kullanılan prosedürlerdir. Ekstraksiyon işlemlerinde genellikle metanol, etanol, aseton, etil asetat, DMSO ve su gibi çözücüler kullanılmaktadır. Özellikle antosiyanin içeriği yüksek renkli bitkilerden ekstrakt hazırlanırken bu çözücülerin asidifiye edilmiş formları da tercih edilmektedir. Bu amaçla formik, asetik, fosforik, tartarik ve sitrik asit gibi zayıf asitlerin $\% 3(\mathrm{v} / \mathrm{v})$ oranına kadar, hidroklorik asit gibi kuvvetli asitlerin ise \% 1 (v/v) oranına kadar kullanılması önerilmektedir. Ekstraksiyon sıcaklığının ise $20^{\circ} \mathrm{C}$ ile $50^{\circ} \mathrm{C}$ arasında olması, kimyasal yapının bozunmasından dolayı $70^{\circ} \mathrm{C}$ 'nin üzerine çıkılmaması tavsiye edilmektedir. Ekstraksiyon işlemi için maserasyon, sokslet ekstraksiyonu, ultrasonik ses dalgaları ile ekstraksiyon, süper kritik sıvı ekstraksiyonu, basınçlı sıv1 ekstraksiyonu ve hızlandırılmış çözücü ekstraksiyonu gibi yöntemler kullanılmaktadır [9]. Bu nedenlerden dolayı çalışmada kullanılan L. officinalis meyve örnekleri önce kurutularak toz haline getirildi. Ardından toz halindeki örnekler etanol, DMSO ve bu çözücülerin \% 0.5 oranında $\mathrm{HCl}$ içeren formları ile $45^{\circ} \mathrm{C}^{\prime}$ de 24 saat maserasyon yöntemiyle inkübe edilerek dört farklı L. officinalis ekstraktı hazırland1.

Doğal ürün ekstraktlarının in vitro antioksidan aktivitelerinin değerlendirilmesi bu ürünlerin beslenme ve gıda teknolojisi alanlarında kullanımının bir ön çalışması niteliğinde olmaktadır. Ekstraktta bulunan her bir antioksidan maddenin konsantrasyonunu tek tek belirlemek yerine, en az iki farklı yöntem ile desteklenmek koşuluyla toplam antioksidan kapasitesinin değerlendirilmesi giderek daha da kabul görür hale gelmektedir [19]. Bitkisel kaynaklardan elde edilen ekstraktların antioksidan etkinliklerini belirlemede farklı prensiplere dayanan Folin-Denis yöntemi, FolinCiocalteu yöntemi, permanganat titrasyonu, demir indirgeyici antioksidan güç (FRAP), oksijen radikallerini absorblama kapasitesi (ORAC) ve DPPH radikal temizleme aktivitesi gibi çeşitli yöntemler kullanılmaktadır [8,9]. Bu nedenle bu çalışmada ekstraktların antioksidan özellikleri elektron transferine dayalı olarak ölçüm gerçekleştiren dört farklı yöntem (toplam fenolik ve flavonoid madde tayini, DPPH radikal temizleme aktivitesi ve demir indirgeyici güç tayini) kullanılarak belirlendi ve sonuçlar Tablo 1'de sunuldu. 
Tablo 1. Farklı çözücülerle hazırlanan L. officinalis ekstraktlarının antioksidan özellikleri ${ }^{a}$ Etanollü ekstrakta göre anlamlı fark görüldü $(\mathrm{p}<0.05)$

${ }^{\mathrm{b}}$ Asidifiye etanollü ekstrakta göre anlamlı fark görüldü $(\mathrm{p}<0.05)$

${ }^{\mathrm{c}} \mathrm{DMSO}$ 'lu ekstrakta göre anlamlı fark görüldü $(\mathrm{p}<0.05)$

\begin{tabular}{lllll}
\hline Ekstrakt Türü & $\begin{array}{l}\text { Toplam } \\
\text { Fenolik } \\
\text { Madde } \\
\text { Miktarı }\end{array}$ & $\begin{array}{l}\text { Toplam } \\
\text { Flavonoid } \\
\text { Madde } \\
\text { Miktarı* }\end{array}$ & $\begin{array}{l}\text { Demir } \\
\text { Indirgeyici } \\
\text { Güç }^{* * * * *}\end{array}$ & $\begin{array}{l}\text { DPPH Radikal } \\
\text { Temizleme } \\
\text { Aktivitesi }^{* * * * *}\end{array}$ \\
\hline Etanollü & $8.14 \pm 0.11$ & $1.15 \pm 0.14$ & $10.7 \pm 1.00$ & $3.174 \pm 0.022$ \\
DMSO'lu & $34.6 \pm 0.94^{\mathrm{a}, \mathrm{b}}$ & $5.28 \pm 0.25^{\mathrm{a}, \mathrm{b}}$ & $42.7 \pm 0.83^{\mathrm{a}, \mathrm{b}}$ & $0.282 \pm 0.001^{\mathrm{a}, \mathrm{b}}$ \\
Asidifiye Etanollü & $16.0 \pm 1.16^{\mathrm{a}}$ & $3.85 \pm 0.13^{\mathrm{a}}$ & $19.6 \pm 0.39^{\mathrm{a}}$ & $0.474 \pm 0.028^{\mathrm{a}}$ \\
Asidifiye DMSO'lu & $76.6 \pm 0.94^{\mathrm{a}, \mathrm{b}, \mathrm{c}}$ & $17.3 \pm 1.06^{\mathrm{a}, \mathrm{b}, \mathrm{c}}$ & $115.4 \pm 7.37^{\mathrm{a}, \mathrm{b}, \mathrm{c}}$ & $0.213 \pm 0.050^{\mathrm{a}, \mathrm{b}, \mathrm{c}}$ \\
\hline
\end{tabular}

*Toplam fenolik madde miktarları mg gallik aside eşdeğer/g örnek olarak verildi.

** Toplam flavonoid madde miktarları mg kuersetine eşdeğer/g örnek olarak verildi.

**** Demir indirgeyici güç değerleri mg askorbik aside eşdeğer/g örnek olarak verildi.

**** DPPH radikal temizleme aktiviteleri $\mathrm{SC}_{50}$ değerleri $(\mathrm{mg} / \mathrm{mL})$ olarak verildi.

Elde edilen bulgulara göre DMSO'lu ekstraktın ölçülen tüm antioksidan parametrelerdeki değerlerinin etanollü ekstrakta göre istatistiksel olarak anlamlı derecede yüksek olduğu görüldü $(\mathrm{p}<0.05)$. Literatürde L. officinalis meyvelerinden çeşitli çözücülerle hazırlanan ekstraktların antioksidan özelliklerinin incelendiği çalışmalar mevcuttur. Celep ve arkadaşları L. officinalis meyvelerinden metanol ile hazırladıkları ekstraktın toplam fenolik madde, toplam flavonoid madde, DPPH radikal temizleme aktivitesi $\left(\mathrm{SC}_{50}\right)$ ve FRAP değerlerini g örnek başına sirasıyla $23.64 \mathrm{mg}$ gallik asit eşdeğeri, $16.87 \mathrm{mg}$ kuersetin eşdeğeri, $0.795 \mathrm{mg} / \mathrm{mL}$ ve $0.57 \mathrm{mM} \mathrm{FeSO}_{4}$ eşdeğeri olarak bildirmişlerdir [13]. Orhan ve Akkol L. officinalis meyvelerinden diklormetan, etil asetat, aseton, metanol ve su ile hazırladıkları ekstraktların toplam fenolik madde değerlerinin $\mathrm{g}$ örnek başına 14.63-64.43 mg gallik asit eşdeğeri arasında değiștiğini gösterirlerken [12], Kolaylı ve arkadaşları ise $L$. officinalis meyvelerinden hazırladıkları sulu ekstraktın DPPH radikal temizleme aktivitesini $\left(\mathrm{SC}_{50}\right) 0.0286 \mathrm{mg} / \mathrm{mL}$ olarak bildirmişlerdir [1]. Karahalil ve Şahin ise L. officinalis meyvelerinden hazırlanan metanollü ekstraktın toplam fenolik madde, toplam flavonoid madde ve FRAP değerlerini 100 g kuru ağırlık başına sırasıyla $1.094 \mathrm{mg}$ gallik asit eşdeğeri, $0.08 \mathrm{mg}$ kuersetin eşdeğeri ve $28.55 \mathrm{mM}$ Fe(II) eşdeğeri olarak raporlamışlardır [20]. Bu açıdan bakıldığında etanollü ve DMSO'lu L. officinalis ekstraktlarının antioksidan aktivite değerlerinin literatür ile uyumlu olduğu görülmektedir. Aradaki küçük farklılıkların kullanılan meyve örneklerinin toplandığı bölgenin coğrafi özellikleri, toplanma zamanı, olgunluk dereceleri ile kullanılan ekstraksiyon metodu ve kullanılan çözücü türünün farklı olması gibi parametrelerden kaynaklanmış olabileceği düşünülmektedir.

Diyetsel fenolik bileşikler en önemli doğal antioksidan maddeler olup, meyve, sebze, tahıl ve çay gibi yiyecek ve içeceklerde bol miktarda bulunmaktadırlar. Fenolik bileşiklerin güçlü antioksidan ve anti-inflamatuvar özellikleri bilinmekle birlikte, bu özelliklerinin aromatik halka yapıları ve hidroksil gruplarının elektron vericisi özellikleri ile ROS'ları temizleme özelliklerinden kaynaklandığı bildirilmektedir. Fenolik bileşiklerin B halkasındaki (özellikle 3' ve 4' pozisyonlardaki) hidroksil gruplarının ROS'ların yakalanmasında son derece aktif oldukları ileri sürülmektedir. $\mathrm{Bu}$ nedenle, hidroksil gruplarının varlığı, pozisyonu ve toplam sayısı, antioksidan aktivitenin gücünü büyük ölçüde etkilemektedir [8]. Fenolik bileşikler bitkisel kaynaklarda çok basit yapılı aglikon halde bulunabildikleri gibi oldukça kompleks (başka bileşiklerle konjuge halde) halde de bulunabilmektedirler. Genel kanı antioksidan aktivitenin hidroksil grubu sayısıyla orantılı olarak arttığı ve glikozilasyon derecesi ile orantılı şekilde azaldığ 1 yönündedir [21]. Bu nedenle bazı araştırmacılar polar çözücülerle yapılan ekstraksiyon işleminde ortama uygun hacimlerde asit 
eklenmesinin ekstraktın toplam fenolik madde içeriğini ve antioksidan gücünü arttırabileceğini ileri sürmektedirler [22]. Buradan hareketle çalışmanın ikinci aşamasında \% 0.5 (v/v) $\mathrm{HCl}$ ilavesi ile hazırlanan asidifiye etanol ve DMSO ile hazırlanan L. officinalis ekstraktlarının antioksidan özellikleri belirlendi ve sonuçlar Tablo 1'de sunuldu. Gerçekleştirilen asidifikasyon işleminin tüm ölçülen antioksidan parametrelerdeki değerleri ekstraktların ham hallerine göre istatistiksel olarak anlamlı derecede arttırdığ görüldü $(\mathrm{p}<0.05)$. Literatürde çeşitli doğal ürünlerden elde edilen ekstraktların antioksidan özelliklerinin uygulanan asidifikasyon prosedürü ile değiştiğini gösteren çalışmalar mevcuttur. Komes ve arkadaşları geleneksel tedavide kullanılan bazı tıbbi bitkilerden (Melissa officinalis, Thymus serpyllum, Lavandula officinalis Miller, Rubus fruticosus, Urtica dioica ve Olea europea) hazırladıkları asidifiye etanollü ekstraktların toplam flavonoid içerik, 2,2'azino-bis(3-etilbenzotiazolin-6-sülfonik asit) $\left(\mathrm{ABTS}^{+}\right)$antioksidan kapasite ve FRAP değerlerinin sadece etanollü ekstraktlara göre daha yüksek olduğunu gösterirlerken [23], Kopjar ve arkadaşları beyaz, sarı ve siyah çaydan asidifiye metanol ile hazırlanan ekstraktların toplam fenolik içerik, tannin içeriği, DPPH ve ABTS antioksidan aktivite değerlerinin sadece metanol ile hazırlanan ekstraktlardan daha fazla olduğunu bildirmişlerdir [24]. Pithecellobium dulce meyvelerinden hazırlanan farklı ekstraktların antioksidan özelliklerinin incelendiği bir çalışmada asidifiye metanollü ekstraktın toplam antosiyanin miktarı, toplam flavonoid miktarı, askorbik asit miktarı, DPPH radikal temizleme aktivitesi, indirgeyici güç ve metal şelatlama aktivitesi değerlerinin metanollü ekstrakta göre daha yüksek seviyelerde olduğu gösterilmiştir [25]. Değişik türdeki üzüm atıklarından elde edilen ekstraklarda yapılan bir çalışmada asidifiye etanollü ekstraktların toplam fenolik ve flavonoid içerik değerlerinin sadece etanollü ekstrakta göre daha yüksek olduğu gösterilirken [26], Dischistocalyx sp. bitkisinin yapraklarından hazırlanan sulu, etanollü ve asidifiye etanollü ekstraktların antioksidan özelliklerinin değerlendirildiği bir diğer çalışmada ise en yüksek flavonoid içerik değerinin asidifiye etanollü ekstraktta elde edildiği bildirilmiştir [27].

Bununla birlikte gerek doğal ürün ekstraklarına uygulanan asidifikasyon işleminin gerekse de aglikon haldeki polifenolik bileşiklerin biyolojik aktivitelerinin glikozile hallerine göre daha etkili olduğu da çeşitli çalışmalarda ortaya konulmuştur. Mushtaq ve arkadaşları Citrus limonum meyve rezidülerinden metanol, $\% 5$ asidifiye metanol ve \% 10 asidifiye metanol ile hazırlanan ekstraktların toplam polifenolik içerik değerlerinin asidifikasyon işleminden pozitif olarak etkilendiğini göstermişlerdir. Ekstraktların DPPH radikal temizleme ve antimutajenik aktiviteleri de bu sonuçlarla orantılı şekilde bulunmuştur [28]. Kuersetin bir flavonol türevi olup, glikozile hallerinden biri rutin (kuersetin-3-O-rutinosid) olarak bilinmektedir. Yapılan bir çalışmada kuersetinin DPPH antiradikal aktivitesinin rutinden daha fazla olduğu gösterilmiştir. Ayrıca yine aynı çalışmada kuersetinin HepG2 karaciğer kanseri hücre serisindeki sitotoksik ve antigenotoksik etkisinin rutine göre istatistiksel olarak daha fazla olduğu bildirilmiştir [29]. Luteolin ve luteolin-7glikozid üzerine yapılan bir başka çalışmada ise luteolinin DNA ve lipid hasarını önleyici etkisinin glikozidik formuna göre daha etkili olduğu gösterilmiştir [30].

$\mathrm{Bu}$ çalışma asidifikasyon işleminin L. officinalis ekstraktların üzerindeki etkisini inceleyen ilk çalışma olup, çalışma bulgularına göre uygulanan asidifikasyon işleminin L. officinalis ekstraktlarının antioksidan özelliklerini istatistiksel olarak anlamlı derecede arttırdığı görülmektedir. Asidifikasyon prosedürü ile hazırlanan ekstraktlarda daha yüksek antioksidan aktivitenin gözlenmesi uygulanan işleminin konjuge fenolik bileşikleri serbest forma geçirdiğini düşündürmektedir. Antioksidan aktivite değerlerindeki bu yükselmenin biyolojik aktivitelere ne oranda yansıdığının gösterilebilmesi için daha kapsamlı karakterizasyon ve biyolojik aktivite çalışmaları gerekmektedir.

\section{Teşekkür}

Bitki kimliklendirilmesi konusundaki yardımlarından dolayı Gümüşhane Üniversitesi Mühendislik ve Doğa Bilimleri Fakültesi öğretim üyesi Yrd. Doç. Dr. İbrahim Turan’a teşekkür ederiz. 


\section{Kaynaklar}

[1] Kolayli, S., Kucuk, M., Duran, C., Candan, F., Dincer, B., "Chemical and antioxidant properties of Laurocerasus officinalis Roem. (cherry laurel) fruit grown in the Black Sea region", Journal of Agricultural and Food Chemistry, 2003, 51: 7489-7494.

[2] Demir, S., Turan, I., Demir, F., Ayazoglu Demir, E., Aliyazicioglu, Y., "Cytotoxic effect of Laurocerasus officinalis extract on human cancer cell lines", Marmara Pharmaceutical Journal, 2017, 21: 121-126.

[3] Senayli, A., Sahin, A., Senayli, Y., Elmastas, M., "Evaluation the anti-diabetic activity of cherry laurel (Laurocerasus officinalis)", The Open Conference Proceedings Journal, 2012, 3: 8-12.

[4] Erdemoglu, N., Kupeli, E., Yesilada, E., "Anti-inflammatory and antinociceptive activity assessment of plants used as remedy in Turkish folk medicine", Journal of Ethnopharmacology, 2003, 89: 123-129.

[5] Czerska, M., Mikolajewska, K., Zielinski, M., Gromadzinska, J., Wasowicz, W., "Today's oxidative stress markers", Medycyna Pracy, 2015, 66(3): 393-405.

[6] Hussain, T., Tan, B., Yin, Y., Blachier, F., Tossou, M.C.B., Rahu, N., "Oxidative stress and inflammation: What polyphenols can do for us?", Oxidative Medicine and Cellular Longevity, 2016, Article ID: 7432797, doi: 10.1155/2016/7432797.

[7] Xu, D.P., Li, Y., Meng, X., Zhou, T., Zhou, Y., Zheng, J., Zhang, J.J., Li, H.B., "Natural antioxidants in foods and medicinal plants: Extraction, assessment and resources", International Journal of Molecular Sciences, 2017, 18: 96, doi: 10.3390/ijms18010096.

[8] Zhang, H., Tsao, R., "Dietary polyphenols, oxidative stress and antioxidant and antiinflammatory effects", Current Opinion in Food Science, 2016, 8: 33-42.

[9] Dai, J., Mumper, R.J., "Plant phenolics: Extraction, analysis and their antioxidant and anticancer properties", Molecules, 2010, 15: 7313-7352.

[10] Suganya Devi, P., Saravanakumar, M., Mohandas, S., "Identification of 3-deoxyanthocyanins from red sorghum (Sorghum bicolor) bran and its biological properties", African Journal of Pure and Applied Chemistry, 2011, 5(7): 181-193.

[11] Suresh, R., Saravanakumar, M., Suganyadevi, P., "Anthocyanins from Indian Cassava (Manihot esculenta Crantz) and its antioxidant properties", International Journal of Pharmaceutical Sciences and Research, 2011, 2(7): 1819-1828.

[12] Orhan, I.E., Akkol, E.K., "Estimation of neuroprotective effects of Laurocerasus officinalis Roem. (cherry laurel) by in vitro methods", Food Research International, 2011, 44: 818-822.

[13]Celep, E., Aydin, A., Yesilada, E., "A comparative study on the in vitro antioxidant potentials of three edible fruits: Cornelian cherry, Japanese persimmon and cherry laurel", Food and Chemical Toxicology, 2012, 50: 3329-3335.

[14] Slinkard, K., Singleton, V.L., "Total phenol analysis: automation and comparison with manual methods", American Journal of Enology and Viticulture, 1977, 28: 49-55.

[15] Moreno, M.I., Isla, M.I., Sampietro, A.R., Vattuone, M.A., "Comparison of the free radicalscavenging activity of propolis from several regions of Argentina", Journal of Ethnopharmacology, 2000, 71(1-2): 109-114.

[16] Oyaizu, M., "Studies on product of browning reaction prepared from glucose amine", Japanese Journal of Nutrition, 1986, 44: 307-315.

[17]Cuendet, M., Hostettmann, K., Potterat, O., "Iridoid glucosides with free radical scavenging properties from Fagraea blumei", Helvetica Chimica Acta, 1997, 80: 1144-1152.

[18]Lin, K.H,, Yeh, H., Lin, S.Y., Yang, C.M., Tsai, H.J., Tsai, J.J., Chao, P.Y., "Antioxidant activities of methanol extracts from selected Taiwanese herbaceous plants", Journal of Food and Nutrition Research, 2014, 2(8): 435-442.

[19]Lima, A.J.B., Correa, A.D., Saczk, A.A., Martins, M.P., Castilho, R.O., "Anthocyanins, pigment stability and antioxidant activity in jabuticaba [Myrciaria cauliflora (Mart.) O. Berg]", Revista Brasileira de Fruticultura, 2011, 33(3): 877-887. 
[20] Karahalil, F.Y., Sahin, H., "Phenolic composition and antioxidant capacity of cherry laurel (Laurocerasus officinalis Roem.) sampled from Trabzon region, Turkey", African Journal of Biotechnology, 2011, 10(72): 16293-16299.

[21]Fukumoto, L.R., Mazza, G., "Assessing antioxidant and prooxidant activities of phenolic compounds", Journal of Agricultural and Food Chemistry, 2000, 48: 3597-3604.

[22] Adiyaman, P., Hemalatha, G., Kanchana, S., Parvathi, S., "Determination of the total polyphenolic content and total antioxidant capacity of commonly consumed foods in Tamil Nadu", International Journal of Science and Nature, 2016, 7(4): 782-785.

[23] Komes, D., Belscak-Cvitanovic, A., Horzic, D., Rusak, G., Likic, S., Berendika, M., "Phenolic composition and antioxidant properties of some traditionally used medicinal plants affected by the extraction time and hydrolysis", Phytochemical Analysis, 2011, 22: 172-180.

[24]Kopjar, M., Tadic, M., Pilizota, V., "Phenol content and antioxidant activity of green, yellow and black tea leaves", Chemical and Biological Technologies in Agriculture, 2015, 2: 1, doi: 10.1186/s40538-014-0028-7.

[25]Ponmozhi, P., Geetha, M., Saravana Kumar, M., Suganya Devi, P., "Extraction of anthocyanin and analysing its antioxidant properties from Pithecellobium dulce fruit pericarp", Asian Journal of Pharmaceutical and Clinical Research, 2011, 4(1): 41-45.

[26]El Gengaihi, S., Aboul Ella, F.M., Emad, M.H., Shalaby, E., Doha, H., "Antioxidant activity of phenolic compounds from different grape wastes", Journal of Food Processing and Technology, 2014, 5: 2, doi: 10.4172/2157-7110.1000296.

[27] Andzi-Barhe, T., Massala, K.K., Obame Engonga, L.C., Lebibi, J., "Phytochemical studies, total phenolic and flavonoids content and evaluation of antiradical activity of the extracts of the leaves from Dischistocalyx sp. (Acanthacees)", Journal of Pharmacognosy and Phytochemistry, 2015, 3(6): 174-178.

[28] Mushtaq, M., Sultana, B., Anwar, F., Batool, S., "Antimutagenic and antioxidant potential of aqueous and acidified methanol extracts from Citrus limonum fruit residues", Journal of the Chilean Chemical Society, 2015, 60(2): 2979-2983.

[29]Ramos, A.A., Lima, C.F., Pereira, M.L., Fernandes-Ferreira, M., Pereira-Wilson, C., "Antigenotoxic effects of quercetin, rutin and ursolic acid on HepG2 cells: Evaluation by the comet assay", Toxicology Letters, 2008, 177: 66-73.

[30]Lima, C.F., Fernandes-Ferreira, M., Pereira-Wilson, C., "Phenolic compounds protect HepG2 cells from oxidative damage: Relevance of glutathione levels", Life Sciences, 2006, 79: 20562068. 